\title{
PUTUSAN PENGADILAN TENTANG MELAWAN HUKUM DALAM TINDAK PIDANA KORUPSI
}

\section{Oleh :}

\section{Nur Basuki Minarno}

(e-mail: Perspektif_keadilan@yahoo.com) Dosen Fakultas Hukum UNAIR

JL. Dharmawangsa Dalam Selatan Surabaya

\begin{abstract}
From this research, it is found out that firstly, the concept of power belongs to the regime of Administrative Law. To prove the element of misuse of power, therefore, it is necessary apply legal concept under Administrative Law regime. In practice, however, to determine whether there is an element of misuse of power, court relies upon principle of reasonableness and carefulness as a parameter that are only suitable to determine materially unlawful act. Doing as such, the court mixes up two parameters of different legal regimes in determining the element of misuse of power.
\end{abstract}

Keyword: court, unlawful act, misuse of power

Dalam UU Nomor 31 Tahun 1999 jo. UU Nomor 20 Tahun 2001 tentang Pemberantasan Tindak Pidana Korupsi (selanjutnya UU PTPK) menentukan melawan hukum (Pasal 2) dan penyalahgunaan wewenang (Pasal 3) sebagai bagian inti delik (bestanddeel delict) dalam tindak pidana korupsi.

Konsep melawan hukum dalam Penjelasan Pasal 2 ayat (1) UU PTPK diartikan melawan hukum formiel dan materiel. Pengertian di atas dinyatakan tidak berlaku lagi dengan adanya Putusan Mahkamah Konstitusi, oleh karenanya konsep melawan hukum harus diberi pengertian melawan hukum formil.

Dinyatakan melawan hukum jika perbuatan tersebut bertentangan dengan undang-undang (legislasi). Di sisi lain dalam UU PTPK tidak memberikan penjelasan tentang konsep penyalahgunaan wewenang, oleh karenanya dalam putusan pengadilan terjadi beraneka ragam penafsiran. Beberapa putusan pengadilan mencampur adukan antara konsep melawan hukum dengan penyalahgunaan wewenang, padahal diantara kedua konsep tersebut adalah berbeda.

Dari kajian terhadap putusan pengadilan, dalam praktek peradilan ditemukan surat dakwaan dari penuntut umum terhadap tersangka/terdakwa (subyek delik) bukan pejabat atau pegawai negeri mendasarkan pada perbuatan penyalahgunaan wewenang. Terjadi juga pada hal sebaliknya, subyek deliknya adalah pejabat atau pegawai negeri dengan didakwa melakukan perbuatan melawan hukum. Dari hasil kajian teori 
terhadap praktek peradilan seperti tersebut di atas dapat dinyatakan telah terjadi kekeliruan. Pejabat atau pegawai negeri melakukan perbuatan "melawan hukum" dalam bentuknya penyalahgunaan wewenang.

Penyalahgunaan wewenang tidak dapat dilakukan oleh seseorang yang tidak mempunyai jabatan/ kedudukan (publik).

Dicantumkan unsur "melawan hukum" sebagai bagian inti delik pada Pasal 2 UU PTPK di samping unsur "penyalahgunaan wewenang" sebagai bagian inti delik pada Pasal 3 UU PTPK, dalam praktek peradilan, parameter "melawan hukum" dipergunakan sebagai parameter untuk mengukur/menilai terjadinya penyalahgunaan wewenang, padahal parameter "penyalahgunaan wewenang" dengan parameter "melawan hukum" merupakan dua hal yang berbeda.

\section{Parameter Melawan Hukum Dalam Tindak Pidana Korupsi}

Unsur melawan hukum dalam UU PTPK meliputi melawan hukum formiel dan materiel. Ditentukan dalam Pasal 2 beserta Penjelasannya UU PTPK, parameter "melawan hukum formiel" adalah bertentangan dengan peraturan perundang-undangan, sedangkan parameter "melawan hukum materiel" adalah bertentangan dengan nilai kepatutan dan keadilan masyarakat.

Parameter bertentangan dengan "peraturan perundang-undangan" yang dipakai untuk mengukur/menilai suatu perbuatan melawan hukum atau tidak, kembali pada persoalan semula: apakah rumusan tersebut tidak bertentangan dengan asas legalitas?

\section{Berdasarkan pada Pasal 2 UU} PTPK, "nilai kepatutan dan keadilan masyarakat" dipakai sebagai parameter untuk mengukur/menilai suatu perbuatan tersebut tercela dan patut untuk dipidana.

Nilai kepatutan/keseksamaan "maatschappelijke zorgvuldigheid" yang ditarik dari prinsip " materiele wederrechtelijkheid" tidaklah identik dengan "behoorlijk" dalam kaitannya dengan algemene beginselen van behoorlijk bestuur. (Philipus M.Hadjon, 1987: 122124)

Dalam praktek peradilan (putusan pengadilan), asas kepatutan dipakai sebagai parameter untuk mengukur/menilai penyalahgunaan wewenang dalam kategori wewenang bebas (diskresi).

\section{Peraturan Perundang-undangan}

Konsep Melawan hukum dalam UU PTPK meliputi melawan hukum formiel dan materiel. Pada unsur melawan hukum formiel, parameter yang dipakai adalah bertentangan dengan peraturan perundang-undangan (lihat Penjelasan Pasal 
2 ayat (1) UU PTPK).

Konsep melawan hukum formiel dalam UU PTPK mengalami perkembangan, tidak lagi untuk menyatakan dasar patut dipidananya perbuatan dengan undang-undang (wet), melainkan didasarkan pada peraturan perundangundangan. Konsep melawan hukum dalam UU PTPK berbeda dengan asas legalitas.

Telaah secara filosofis atas asas legalitas bahwa kemerdekaan seseorang yang merupakan hak kodrat manusia tidak boleh dirampas oleh siapapun juga kecuali dengan cara-cara demokratis. (Philipus M.Hadjon, 1987: 42-45) Konkritisasi caracara yang demokratis ada dalam undangundang dan peraturan daerah, karena kedua produk peraturan perundangundangan itulah tercermin persetujuan dari rakyat. Hal tersebut sudah mempunyai kekuatan yuridis dengan diundangkannya UU Nomor 10 Tahun 2004 yang pada pokoknya menyatakan bahwa UU dan Perda yang dapat mencantumkan sanksi pidana.

Konsep melawan hukum formiel dalam UU PTPK yang mendasarkan pada peraturan perundang-undangan untuk dipakai sebagai dasar patut dipidananya suatu perbuatan telah menyimpang dari asas legalitas, nullum delictum nulla poena sine praevia lege poenali.
Dalam praktek peradilan untuk menyatakan bahwa perbuatan terdakwa melawan hukum formiel dengan suatu pembuktian bahwa perbuatan yang dilakukan terdakwa bertentangan dengan Peraturan Pemerintah, Surat Keputusan Presiden, Surat Keputusan Menteri. Terkait dengan hal tersebut, pertanyaan yang dapat diajukan adalah: apakah tidak bertentangan dengan asas legalitas?

Terkadang dijumpai dalam peraturan perundang-undangan di bawah undang-undang (PP, Peraturan Presiden, SK Presiden, SK Menteri) mengatur suatu hal yang sama sekali baru dan hal itu tidak di atur dalam undang-undang. Contoh yang dapat dikemukakan adalah aturan penggunaan belanja tidak tersangka.

Dalam UU Nomor 17 Tahun 2003, UU Nomor 1 Tahun 2004, maupun UU Nomor 32 Tahun 2004 tidak mengatur tentang prosedur penggunaan anggaran belanja tidak tersangka, tetapi ketentuan tersebut dapat diketemukan dalam PP Nomor 58 Tahun 2005. Jika asas legalitas diartikan pelanggaran terhadap peraturan pe-rundang-undangan, maka perbuatan yang menyimpang dari ketentuan yang ada dalam PP Nomor 58 Tahun 2005, maka perbuatan tersebut dapat diklassifikasikan sebagai perbuatan melawan hukum atau penyalahgunaan wewenang sehingga atas perbuatan 
tersebut dapat dilakukan penuntutan. Permasalahan yang dapat diajukan adalah: apakah dapat menggunakan dasar patut dipidananya perbuatan mendasarkan pada perbuatan yang menyimpang dengan PP?

Menjawab permasalahan di atas, seperti yang telah diuraikan sebelum nya bahwa unsur "melawan hukum" merupakan instrumen/modus dalam tindak pidana korupsi. Parameter yang dapat dipakai untuk menilai ada tidaknya unsur "melawan hukum" adalah peraturan perundang-undang. Perbuatan "melawan hukum" mempunyai implikasi tindak pidana korupsi jika ada kerugian keuangan negara atau perekonomian negara.

Peraturan Pemerintah (termasuk juga S.E. Keputusan Gubernur/ Bupati/Walikota) dipakai dasar untuk menentukan apakah perbuatan tersebut melawan hukum atau tidak, sedangkan dasar penjatuhan pidana menggunakan UU Nomor 17 Tahun 2003 atau UU Nomor 1 Tahun 2004.

\section{Nilai Kepatutan dan Keadilan Masyarakat}

Konsep melawan hukum yang bersifat materiel parameter yang dipakai adalah bertentangan dengan nilai kepatutan dan nilai keadilan masyarakat. Hal tersebut dinyatakan dalam Penjelasan
Pasal 2 ayat (1) UU Nomor 31 Tahun 1999 sebagai berikut: Yang dimaksud dengan "secara melawan hukum" dalam Pasal ini mencakup perbuatan melawan hukum dalam arti formil maupun dalam arti materiil, yakni meskipun perbuatan tersebut tidak diatur dalam peraturan perundang-undangan, namun apabila perbuatan tersebut dianggap tercela karena tidak sesuai dengan rasa keadilan atau norma-norma kehidupan sosial dalam masyarakat, maka perbuatan tersebut dapat dipidana.

Asas legalitas formiel dan materiel pada Pasal 2 UU PTPK sejalan dengan Pasal 11 Konsep R KUHP tahun 2004 yang pada pokoknya dinyatakan melakukan perbuatan melawan hukum jika peraturan perundang-undangan melarang perbuatan tersebut dan diancam dengan pidana atau bertentangan dengan kesadaran hukum masyarakat.

Dalam Penjelasan Konsep R KUHP -2004 memberikan penjelasan atas pengertian "perbuatan yang bertentangan dengan hukum" sebagai berikut: Yang dimaksud dengan "perbuatan yang bertentangan dengan hukum" adalah perbuatan yang dinilai oleh masyarakat sebagai perbuatan yang tidak dapat dilakukan.

Ditentukannya syarat bertentangan dengan hukum, didasarkan pada pertimbangan bahwa menjatuhkan 
pidana pada seseorang yang melakukan suatu perbuatan yang tidak bersifat melawan hukum dinilai tidak adil. Oleh karena itu untuk dapat menjatuhkan pidana, hakim selain harus menentukan apakah perbuatan yang dilakukan itu secara formil dilarang oleh peraturan perundang-undangan dan apakah perbuatan tersebut secara materiel juga bertentangan dengan hukum, dalam arti kesadaran hukum masyarakat. Hal ini wajib dipertimbangkan dalam putusan.

Pembentuk undang-undang dalam menentukan perbuatan yang dapat dipidana, harus memperhatikan keselarasan dengan perasaan hukum yang hidup masyarakat. Oleh karena itu perbuatan tersebut nantinya tidak hanya bertentangan dengan peraturan perundang-undangan tetapi juga akan selalu bertentangan dengan hukum. Pada umumnya setiap tindak pidana dipandang bertentangan dengan hukum, namun dalam keadaan khusus menurut kejadiankejadian konkrit, tidak menutup kemungkinan perbuatan tersebut tidak bertentangan dengan hukum. Dalam hal demikian, pembuat tindak pidana membuktikan bahwa perbuatannya tidak bertentangan dengan hukum.

Dalam Pasal 11 Konsep $\mathrm{R}$ KUHP-2004 sejalan dengan keseimbangan asas legalitas formil dan materiel dan juga menegaskan ke- seimbangan unsur melawan hukum formal dan materiel, serta mendasarkan pada perbuatan dan pembuat tindak pidananya (daad-dader-strafrecht).

Atas dasar rumusan Pasal 11 Konsep R KUHP-2004 beserta Penjelasannya, dapat disimpulkan bahwa dalam Konsep R KUHP-2004 menganut melawan hukum materiel yang berfungsi negatif.

Dalam konsep sebelumnya (sampai dengan Konsep 2002) belum ada penegasan mengenai pedoman/ kriteria/ rambu-rambu untuk menentukan sumber hukum materiel mana yang dapat dijadikan sebagai sumber hukum (sumber legalitas). Namun dalam perkembangan Konsep terakhir (Konsep Desember 2004 yang sudah diserahkan kepada Menkumham pada tanggal 4 Januari 2005), sudah dirumuskan pedoman/kriteria/ramburambunya, yaitu "sepanjang sesuai dengan nilai-nilai Pancasila dan/atau prinsip-prinsip hukum umum yang diakui oleh masyarakat bangsa- bangsa".

Jadi, pedoman/kriterianya bertolak dari nilai-nilai nasional maupun internasional. Sesuai dengan nilai-nilai nasional (Pancasila), artinya sesuai dengan nilai/ paradigma moral religius, nilai/paradigma kemanusiaan (humanis), nilai/paradigma kebangsaan, nilai/ paradigma demokrasi (kerakyatan/hikmah kebijaksanaan), dan nilai/paradigma 
keadilan sosial. Patut dicatat, bahwa rambu-rambu yang berbunyi "sesuai dengan prinsip-prinsip hukum umum yang diakui oleh masya-rakat bangsa-bangsa", mengacu/ bersumber dari istilah "the general principles of law recognized by the community of nations" yang terdapat dalam pasal 15 ayat 2 ICCPR (International Covenant on Civil and Political Rights). (Barda N. Arief, 2005:89).

Dalam Putusan Mahkamah Agung tanggal 15 Desember 1983 No. 275 K/Pid//982 dalam "Kasus Korupsi di Bank Bumi Daya" untuk pertama kali Mahkamah Agung memberikan arti tentang korupsi, baik secara formiel maupun materiel. Dalam kasus ini, Mahkamah Agung menyatakan bahwa korupsi adalah perbuatan yang tidak patut, tercela, dan menusuk perasaan hati masyarakat banyak. Ukurannya adalah asas-asas hukum yang bersifat umum menurut kepatutan dalam masyarakat.

Apakah nilai kepatutan/keseksamaan masyarakat (maatschappelijke zorgvuldigheid) dalam unsur melawan hukum materiel sejajar dengan "behoorlijkheid" dalam kaitannya dengan "algemene beginselen van behoorlijk bestuur"?

Hasil kajian dari Philipus M. Hadjon atas pendapat dari Meyer dan P. De Haan c.s. dan sekaligus mengkaitkan dengan Surat Edaran Mahkamah Agung tanggal 25 Pebruari 1977 No. M.A./Pemb/0159/77 menyatakan bahwa : "meskipun kepatutan yang harus diperhatikan oleh penguasa (rumusan Mahkamah Agung) dapat disejajarkan dengan rumusan Hoge Raad tentang "maatschappelijke zorgvuldigheid" namun hendaklah disadari bahwa antara keduanya terdapat perbedaan yang hakiki dalam isinya. Oleh Mahkamah Agung diingatkan....hendaklah para hakim di dalam mengadili, memperhatikan kriteria/pengertian bahwa suatu hak selalu harus dipandang dalam fungsi sosialnya, artinya hak tersebut tidak mutlak milik individu....".

Di pihak lain, kepatutan dalam masyarakat yang harus diperhatikan oleh penguasa tidak sama maknanya dengan "behoorlijkheid" dalam kaitannya dengan "algemene beginselen van behoorlijk bestuur" meskipun kata "behoorlijk": "patut" (Inggris: proper).... Algemene beginselen van behoorlijk bestuur mengharapkan pemerintah bertingkah laku sepantasnya "als een goed huisvader" (sebagai seorang ayah yang baik); diantaranya yang terpenting adalah : het verbod van willekeur, het verbod van détournement de pouvoir, het verbod tot fair play, het zorgvuldigheidsbeginsel, het rechtszekerheids beginsel, het motiveringsbeginsel, het evenredigheids 
beginsel, het gelijkheids beginsel ". (Philipus M.Hadjon, 1987:122-124)

Dari hasil kajian teoritis tersebut menunjukkan bahwa asas kepatutan/keseksamaan masyarakat (maatschappelijke zorgvuldigheid) yang merupakan unsur melawan hukum materiel berbeda dengan "behoorlijk" dalam kaitannya dengan algemene beginselen van behoorlijk bestuur. Namun demikian di dalam praktek peradilan keduanya saling dipertukarkan.

Saling dipertukarkan antara konsep penyalahgunaan wewenang dengan konsep melawan hukum dapat dilihat dalam Putusan Mahkamah Agung R.I Nomor 380K/Pid/2001 tanggal 10 Maret 2001 yang dalam ratio decidendinya dinyatakan: bahwa di persidangan Pengadilan Tingkat Pertama telah terbukti fakta sebagaimana dikemukakan oleh Jaksa Penuntut Umum dalam memori kasasinya tersebut, yang pada pokoknya sebagaimana berikut :bahwa terdakwa telah memproses dan mencairkan klaim P.T. Bank Bali atas transaksi dengan P.T. BDNI yang tidak didaftarkan atau terlambat didaftarkan pada Bank Indonesia atau BPPN, yang berdasarkan alat bukti surat-surat dan keterangan saksi-saksi oleh Pejabat Bank Indonesia klaim tersebut beberapa kali ditolak, di dalam klaim P.T. Bank Bali tersebut telah dimasukkan bunga yang pemberiannya tidak disetujui oleh Bank Indonesia sebagaimana ditegaskan dalam Memorandum Divisi Bank Reabilitas tanggal 9 April 1999 No. 008 BL, sebagai hasil perbuatan terdakwa memproses klaim P.T. Bank Bali tersebut oleh Desmi Demas Kepala Urusan Akunting dari Sistem Pembayaran Bank Indonesia telah dilakukan pembayaran klaim sebesar Rp. 904.642.428.369,00 dengan mendebet rekening No. 502.000.002 Bendahara Umum Negara untuk Obligasi dan mengkreditkan ke rekening P.T. Bank Bali Tbk. Di Bank Indonesia No.523.013.00 yang kemudian sejumlah Rp. 546.468.544.738,00 telah di transfer ke rekening P.T. Era Giat Prima, bahwa perbuatan terdakwa tersebut dalam butir 1 menurut pendapat Mahkamah Agung adalah merupakan perbuatan melawan hukum sebagaimana dimaksud dalam Pasal 1 ayat (1) sub a Undang-undang Nomor 3 Tahun 1971 mengingat alasanalasan sebagai berikut: bahwa "perbuatan melawan hukum".

Secara materiel, sebagaimana dimaksud dalam per-timbangan di atas, perbuatan terdakwa tersebut adalah merupakan perbuatan melawan hukum secara materiel, karena perbuatan terdakwa tersebut bertentangan dengan Surat Keputusan Presiden Nomor 26 Tahun 1998, Surat Keputusan Menteri Keuangan R.I. Tanggal 28 Januari 1998, 
Surat Keputusan Bersama Direksi Bank Indonesia dengan Ketua BPPN tanggal 6 Maret I998 Nomor: 30/270/KEP/DIR 1/BPPN/1998

dan tanggal 14 Mei 1999 Nomor :

32/46/KEP/DIR

181/BPPN/1998

bahwa perbuatan terdakwa tersebut adalah memenuhi rumusan perbuatan melawan hukum sebagaimana dimaksud dalam Putusan Pengadilan Mahkamah Agung tanggal 15 Desember 1983 Nomor 275 K/Pid/l982 karena perbuatan terdakwa tersebut merupakan penggunaan dan wewenang secara menyimpang.

Majelis Hakim dalam menjatuhkan Putusan dalam perkara No. 380 K/Pid/2001 mendasarkan pada putusan pengadilan yang telah ada yaitu Putusan Mahkamah Agung tanggal 15 Desember 1983 Nomor 275 K/Pid//982.

Putusan pengadilan Mahkamah Agung tanggal 15 Desember 1983 Nomor $275 \mathrm{~K} / \mathrm{Pid} / \mathrm{l} 982$ menyatakan bahwa perbuatan terdakwa tersebut merupakan "penggunaan kekuasaan dan wewenang secara menyimpang“.

Dalam hal ini Majelis Hakim pada perkara Nomor $380 \mathrm{~K} / \mathrm{Pid} / 2001$ dan perkara Nomor $275 \mathrm{~K} / \mathrm{Pid} / 1983$ berpendapat bahwa konsep melawan hukum materiel identik dengan "penggunaan kekuasaan dan wewenang secara menyimpang".

Dalam hal penggunaan istilah "penggunaan kekuasaan dan wewenang secara menyimpang", pertanyaan yang dapat diajukan adalah : Apakah konsep "penggunaan kekuasaan dan wewenang secara menyimpang" identik dengan konsep "penyalahgunaan wewenang?

Jika jawaban ya, pertanyaannya selanjutnya adalah: apakah konsep penyalahgunaan wewenang ("penggunaan kekuasaan dan wewenang secara menyimpang") identik dengan konsep "melawan hukum secara materiel"?.

Jawaban atas pertanyaan yang pertama dapat ditelusuri dari dakwaan Penuntut Umum maupun bukti-bukti yang ditemukan dalam persidangan. Fakta di persidangan menunjukkan bahwa terdakwa terbukti melakukan perbuatan menyimpang terhadap apa yang ditentukan dalam Surat Keputusan Presiden Nomor 26 Tahun 1998, Surat Keputusan Menteri Keuangan R.I. Tanggal 28 Januari 1998, Surat Keputusan Bersama Direksi Bank Indonesia dengan Ketua BPPN tanggal 6 Maret 1998 Nomor :

30/270/KEP/DIR

1/BPPN/I998

dan tanggal 14 Meil999Nomor :

32/46/KEP/DIR

181/BPPN/I998

Berdasarkan ratio decidendi dalam Putusan Mahkamah Agung Nomor 
$380 \mathrm{~K} / \mathrm{Pid} / 2001$ tanggal 10 Maret 2001 dan Putusan MahkamahAgung tanggal 15 Desember 1983 Nomor 275 K/Pid/1982 dapat ditarik suatu kesimpulan bahwa penggunaan istilah "penggunaan kekuasaan dan wewenang secara menyimpang" adalah identik dengan konsep penyalahgunaan wewenang.

Jawaban atas pertanyaan yang kedua adalah sebagai berikut : telah dipaparkan dalam bab sebelumnya bahwa untuk mengukur penyalahgunaan wewenang dapat mempergunakan asas legalitas atau asas-asas umum pemerintahan yang baik tergantung pada jenis wewenang tersebut (terikat/bebas).

Asas legalitas dipergunakan sebagai parameter dalam kaitannya dengan wewenang terikat, sedangkan asas-asas umum pemerintahan yang baik dipakai sebagai parameter penyalahgunaan wewenang dalam kaitannya dengan wewenang bebas (diskresi), karena asas "wetmatigheid" tidaklah memadai.

Pada kasus di atas penyalahgunaan wewenang terjadi dalam kaitannya dengan wewenang terikat, hal ini bisa dibuktikan dengan melihat ratio decidendi dari Majelis Hakim yang mendasarkan perbuatan menyimpang dari terdakwa terhadap Surat Keputusan Presiden, Surat Keputusan Menteri Keuangan R.I., dan Surat Keputusan Bersama Direksi
Bank Indonesia dengan Ketua BPPN, yang kesemuanya itu adalah peraturan tertulis (written rules).

Parameter untuk menilai melawan hukum adalah peraturan perundang-undangan (melawan hukum formiel) atau kepatutan dan nilai keadilan atau norma-norma kehidupan sosial dalam masyarakat (melawan hukum materiel). Oleh karena itu, parameter penyalahgunaan wewenang dalam kewenangan diskresi berbeda parameternya dengan melawan hukum materiel.

Andi Hamzah memberikan catatan berkaitan dengan parameter melawan hukum yang bersifat materiel dengan menyatakan "dengan mendasarkan pada rasa keadilan masyarakat sangat bersifat karet, dan menjadi sama dengan penyingkiran asas legalitas seperti yang terjadi pada zaman NAZI dengan kata-kata yang sama yaitu: "rasa keadilan masyarakat menuntut agar seseorang dipidana maka orang itu harus dipidana, walaupun tidak tercantum di dalam undang-undang“. (Andi Hamzah, 2005: 121)

Dari uraian tersebut nampak bahwa konsep melawan hukum dalam arti formiel identik dengan penyalahgunaan wewenang dalam wewenang terikat, hal ini dikarenakan parameternya sama yaitu peraturan perundang-undangan (written rules). 
Berbeda halnya antara asasasas umum pemerintahan yang baik dengan nilai kepatutan dan keadilan atau norma-norma kehidupan sosial dalam masyarakat. Asas-asas umum pemerintahan yang baik merupakan norma yang tidak tertulis yang tumbuh dalam praktek penyelenggaraan pemerintah dan dipakai sebagai etika menjalankan pemerintahan, dari mana untuk keadaan tertentu dapat ditarik aturan-aturan hukum yang dapat diterapkan. Dalam hal normanorma kehidupan sosial masyarakat tumbuh dan berkembangnya dalam lingkungan masyarakat yang bersangkutan. (Philipus Mandiri Hadjon,1993 :270)

Saling dipertukarkannya parameter penyalahgunaan wewenang dengan parameter melawan hukum yang bersifat materiel dalam praktek terjadi pula pada Putusan Majelis hakim Pengadilan Negeri Jakarta Pusat yang memeriksa dan mengadili terdakwa Ir. A.T dalam putusan No. 449/Pid.B/2002/PN. Jkt.Pst tanggal 4 September 2002 yang memberikan pengertian bahwa unsur penyalahgunaan wewenang dilakukan penilaian berdasarkan "asas kepatutan", oleh hakim Pengadilan Tinggi Jakarta dalam Putusannya No. 171/Pid.B/2002/ PT.DKI tanggal 17 Januari 2003 sependapat dengan Majelis Hakim Pengadilan Negeri Jakarta Pusat dengan melakukan koreksi mengganti "asas kepatutan" dengan istilah "asas kecermatan".

Pengadilan telah keliru membedakan antara "beleid" (kebijaksanaan) dalam unsur "penyalahgunaan wewenang" dengan pelanggaran terhadap asas "kepatutan" pada unsur "melawan hukum materiel" dengan fungsinya yang positif. Hal tersebut dapat diketemukan juga dalam Putusan Pengadilan Negeri Jakarta Pusat Nomor 2043/Pid.B/2001/ Pn.Jak.Pst, tanggal 1 April 2003 dan Putusan Pengadilan Negeri Jakarta Pusat Nomor 449/Pid.B/2002 P.N. Jkt.Pst tanggal 4 September 2002 jo. Putusan Pengadilan Tinggi DKI No.171/ Pid.B/2002/PT. DKI tanggal 17 Januari 2003.

Berdasarkan Putusan Pengadilan Negeri Jakarta Pusat Nomor 2043/ Pid.B/2001/Pn.Jak.Pst, tanggal 1 April 2003 Direksi Bank Indonesia dinyatakan terbukti secara sah dan menyakinkan terbukti melanggar dakwaan primair (Pasal 1 ayat (1) sub (b) UU Nomor 3 Tahun 1971). Terdakwa dipersalahkan melakukan penyalahgunaan wewenang atas Kebijakan Dewan Direksi Bank Indonesia dengan pertimbangan sebagai berikut : Pemberian dispensasi kliring bagi 18 (delapan belas) Bank yang mengalami Saldo Debet yang bertentangan dengan Surat Keputusan Direksi Bank Indonesia No: 14/35 /Kep/Dir/UPPB tanggal10 September 1981 
tentang Penyelenggaraan Kliring Lokal dan Surat Edaran Direksi Bank Indonesia No: 22/227/UPG tanggal 31 Maret 1990 tentang Otomasi Penyelenggaraan Kliring, Pemberian Kredit likuiditas bagi 18 (delapan belas) Bank yang mengalami Saldo Debet yang bertentangan dengan Surat Keputusan Direksi Bank Indonesia (antara lain) No. 21/54/Kep/Dir tanggal 27 Oktober 1988 tentang Penyediaan Fasilitas Diskonto Dalam Rupiah.

Dalam Putusan Pengadilan Negeri Jakarta Pusat Nomor 2043/ Pid.B/2001/Pn.Jak.Pst, tanggal 1 April 2003 pemberian fasilitas kredit likuiditas terungkap karena fakta hukum sebagai berikut : "Bahwa benar pada tanggal 15 Agustus 1997 Direksi Bank Indonesia yang telah mengadakan rapat berupa Morning and Evening Call (MEC) yang dihadiri oleh Gubernur Bank Indonesia Sudrajat Djiwandono, Terdakwa, Heru Supraptomo, Paul Sutopo Tjokronegoro, Harjono dan Mukhlis Rasyid telah memutuskan sebagai berikut :

"Untuk mengatasi kesulitas likuiditas bank-bank yang disebabkan adanya penarikan dana pihak ketiga dalam jumlah besar sehingga terjadi saldo giro debet di Bank Indonesia, diputuskan untuk diberikan kelonggaran berupa fasilitas saldo debet, sampai dengan gejolak pasang uang mereda. Di samping itu guna menghindari terjadinya rush baik di kantor pusat maupun di kantor cabang telah diputuskan bahwa kantor pusat dan kantor-kantor cabang bank yang mengalami kesulitan likuiditas tetap diperkenankan bersaldo negatif, baik di kantor pusat Bank Indonesia maupun di kantor Bank Indonesia sampai beberapa waktu". (LIhat Putusan Pengadilan Negeri Jakarta Pusat Nomor 2043/Pid.B/2001/ Pn.Jak.Pst, tanggal 1 April 2003, h. 260261).

Selanjutnya dalam putusan tersebut dinyatakan: "bahwa dengan adanya fakta hukum dalam perkara ini, bahwa terdapat 18 (delapan belas) bank yang mengalami saldo debet yang berada di bawah pengawasan terdakwa selaku direktur I Bidang Urusan Pengawasan Bank (UPB) I dan II dimana Giro Wajib Minimumnya (GWM) pada rekening Bank Indonesia telah mengalami minus/kurang karena adanya krisis moneter yang menyebabkan para nasabah mengambil dananya secara besar-besaran (rush) pada bank yang bersangkutan, dan dalam hal yang demikian ke-18 bank tersebut dapat dikualifikasikan sebagai bank-bank yang mengalami kesulitan likuiditas dalam keadaan darurat, oleh karenanya tindakan yang harus dilakukan oleh terdakwa selaku anggota Direksi Bank Indonesia bersamasama anggota Direksi lainnya sesuai dengan Surat Keputusan dan Surat Edaran Bank Indonesia tersebut di atas 
adalah memberikan Fasilitas Diskonto II yang telah diatur baik mengenai jangka waktunya, batas maksimum, tingkat diskonto maupun mekanismenya, bukan dengan cara memberikan fasilitas saldo debet seperti yang dilakukan oleh terdakwa bersama-sama dengan anggota direksi lainnya sesuai dengan Keputusan Rapat Direksi Morning and Evening Call masing-masing tanggal 15 agustus 1997 dan tanggal 20 agustus 1997".

Bahwa fasilitas saldo debet selain tidak diatur di dalam ketentuan hukum dan dengan demikian bukan merupakan fasilitas kredit yang menjadi kewenangan Direksi Bank Indonesia, juga dengan pemberian fasilitas saldo debet tersebut melalui dispensasi pengikutsertaannya dalam kliring tidak dapat ditentukan kriteria-kriteria tertentu, baik jangka waktu, batas maksimum, tingkat diskonto maupun prosedurnya, bahkan juga tidak disertai pengikatan notariil serta tanpa adanya jaminan, sehingga hal yang demikian bukan hanya membuat posisi Bank Indonesia sebagai kreditur tidak aman dan tidak kuat, juga Bank Indonesia dalam hal ini telah mengabaikan prinsipprinsip kehati-hatian (Prudential Banking)". (Lihat Putusan Pengadilan Negeri Jakarta Pusat Nomor 2043/Pid.B/ 2001/Pn.Jak.Pst, tanggal 1 April 2003, h. 282.)
Kebijakan pemberian kredit likuiditas dalam keadaan darurat ini sesuai dengan Petunjuk Presiden pada tanggal 3 Desember 1996 yang saat itu pada pokoknya melarang untuk melakukan tindakan likuidasi atau tindakan-tindakan lain yang dapat menimbulkan gejolak sosial yang sehubungan dengan adanya dua agenda nasional, yaitu Pemilihan Umum dan Sidang Umum MPR-RI, dan hal yang sama dikemukakan kembali oleh Presiden kepada Direksi Bank Indonesia pada tanggal 15April 1997.

Sebenarnya atas dasar Petunjuk Presiden yang tidak menghendaki adanya likuidasi dan tindakan-tindakan lain yang dapat menimbulkan gejolak sosial sebagaimana bunyi pertimbangan majelis hakim di atas, maka pemberian fasilitas kredit likuiditas merupakan kebijakan negara atau Staatsbeleid, yang dalam tataran implementasinya dilaksanakan oleh aparatur negara atau "overheids beleid" di dalam hal ini adalah kebijakan Direksi Bank Indonesia.

Kebijakan Direksi Bank Indonesia secara kolektif institusional tentang pemberian kredit likuiditas dalam kondisi yang darurat, apakah melalui fasilitas dispensasi kliring bagi 18 Bank yang mengalami saldo debet ataukah melalui fasilitas penyediaan kredit likuiditas dengan Diskonto II dalam rupiah hal tersebut merupakan persoalan kebebas- 
an kebijakan (beleidsvrijheid atau Freies Ermessen).

Ketidak tepatan penggunaan "Asas kepatutan" dipakai sebagai parameter untuk menilai adanya penyalahgunaan wewenang dalam kasus Ir. A.T dan Direksi Bank Indonesia, yang pertama, "asas kepatutan" bukanlah merupakan "behoorlijk" dalam kaitannya dengan algemene beginselen van behoorlijk bestuur.

Kedua, penggunaan parameter "materiele weder- rechttelijkheid" untuk menilai penyalahgunaan wewenang adalah tidak tepat, yang semestinya menggunakan parameter pada asas-asas umum pemerintah yang baik.

Ketiga, "asas kepatutan" yang ditarik dari materiele wederrechtelijk tidak dapat dipakai sebagai alasan memidana karena asas kepatutan dalam hukum pidana hanyalah dibenarkan sebagai dasar peniadaan pemidanaan (dalam putusan pengadilan yang dianut adalah melawan hukum materiel yang berfungsi negatif).

Hal serupa terjadi pada kasus mantan 3 (tiga) Direksi Bank Indonesia dalam Putusan Pengadilan Negeri Jakarta Pusat Nomor 2043/Pid.B/2001/ PN.Jak.Pst tanggal 1 April 2003 yang pada intinya dinyata-kan: "kebijakan Direksi Bank Indonesia bertentangan dengan asas kepatutan (materiele wederrechtelijk) oleh karenanya kebijakan dari Direksi Bank Indonesia telah terbukti melakukan penyalahgunaan wewenang".

Terjadinya pertukaran antara konsep penyalahgunaan wewenang dengan konsep melawan hukum dikarenakan adanya keterkaitan kesalahan (schuld) dengan melawan hukum (wederrechtelijk). Andi Hamzah menyatakan : "tidak mungkin ada schuld (kesalahan) tanpa adanya wederrechtelijk (melawan hukum), tetapi mungkin saja ada wederrechtelijk (melawan hukum) tanpa adanya schuld (kesalahan). (Andi Hamzah dalam Indriyanto Seno Adji, 2005:

20)

\section{DAFTAR PUSTAKA}

Adami Chazawi, Hukum Pidana Materiil dan Formil Korupsi Di Indonesia, Bayumedia Publishing, Malang, 2005.

Andi Hamzah, Asas-Asas Hukum Pidana, Yarsif Watampone, Jakarta, 2005.

\section{-------, Korupsi di Indonesia, Masalah dan Pemecahannya, cet.3, Gramedia Pustaka, Jakarta, 1991.
----------, Pemberantasan Korupsi Melalui Hukum Pidana Nasional dan Internasional, Raja Grafindo Persada, Jakarta, 2005.

Barda Nawawi Arief, , Bunga Rampai Kebijakan Hukum Pidana, Citra Aditya Bakti, Bandung, 1996. 
, Kapita Selekta Hukum Pidana, Citra Aditya Bakti, Bandung, 2003.

, Masalah Penegakan Hukum dan Kebijakan penanggulangan Kejahatan, PT Citra Aditya, Bandung, 2001.

Darwan Prinst, Pemberantasan Tindak Pidana Korupsi, Citra Aditya Bakti, Bandung, 2002.

E. Utrect, Pengantar Hukum Administrasi Negara Indonesia, Cet IV, Fakultas Hukum dan Pengetahuan Masyarakat Universitas Negeri Padjajaran, Bandung, 1960.

Edi Yunara, Korupsi dan Pertanggungjawaban Pidana Korupsi Berikut Studi Kasus, Citra Aditya Bakti, Bandung, 2005.

J. Langemeyer, Noyon-G.E., Het Wetboek van Strafrecht, Arnhem : S.Gonda-Quint, 1954.

Jan Remmelink, Hukum Pidana Komentar Atas Pasal-Pasal Terpenting Dari Kitab UndangUndang Hukum Pidana Belanda dan Padanannya Dalam Kitab Undangundang Hukum Pidana Indonesia, Gramedia Pustaka Utama, Jakarta, 2003.

J.E. Sahetapy, (editor penerjemah), Hukum Pidana, Kumpulan Bahan Penataran Hukum Pidana Prof. Dr. D. Schaffmeister, Prof. Dr. Nico Keijzer dan Mr. E. PH. Sutorius, Liberty, Yogjakarta, 1995.

K. Wantjik Saleh, Tindak Korupsi dan Suap, Ghalia Indonesia, Jakarta, 1983.
Komariah Emong Sapardjaja, Ajaran Sifat melawan Hukum Materiil Dalam Hukum Pidana Indonesia, Alumni, Bandung, 2002.

Leden Marpaung, Tindak Pidana Korupsi Pemberantasan dan Pencegahan, Edisi Revisi , Djambatan, Jakarta, 2004.

Moeljatno, Asas-Asas Hukum Pidana, Bina Aksara, Jakarta, 1983.

PP Craig, Administrative Law, Fifth Edition, Sweet\&Maxwell Limited, London, 2003.

Philipus Mandiri Hadjon, Perlindungan Hukum Bagi Rakyat di Indonesia, Sebuah Studi tentang Prinsipprinsipnya, Penanganannya Dalam Lingkungan Peradilan Umum dan Pembentukan Peradilan Administrasi Negara, Bina IImu, Surabaya, 1987.

-----------, Pengertian-Pengertian Dasar Tentang Tindak Pemerintahan, Djumali, Surabaya, 1985.

Phillipus Mandiri Hadjon, Cs, Pengantar Hukum Administrasi Indonesia (Introduction to the Indonesian Administrative), Gadjah Mada University Press, Maret, 2002.

PAF Lamintang, Dasar-Dasar Hukum Pidana Indonesia, Citra Aditya Bakti, Bandung, 1997.

, Delik-Delik Khusus Kejahatan Jabatan dan Kejahatan-Kejahatan Jabatan Tertentu Sebagai Tindak Pidana Korupsi, Pionir Jaya, Bandung, 1991. 